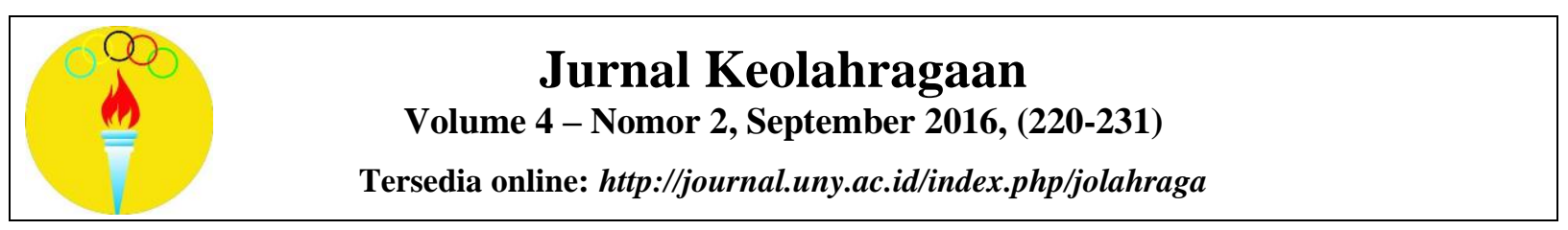

\title{
PENGARUH METODE LATIHAN DAN PERSEPSI KINESTETIK TERHADAP KETERAMPILAN GROUNDSTROKES TENIS LAPANGAN PADA SISWA SD
}

\author{
S. Suryono \\ Universitas PGRI Palembang. Jalan Jendral A. Yani Lorong Gotong Royong No. 9/10, Kota \\ Palembang, Sumatera Utara 30116, Indonesia \\ Korespondensi Penulis. Email: suryono.aba@gmail.com \\ Received: 16 September 2016; Revised: 31 October 2016; Accepted: 23 November 2016
}

\begin{abstract}
Abstrak
Penelitian ini bertujuan untuk mengetahui: (1) Perbedaan pengaruh antara metode demonstrasi dan metode audio visual terhadap keterampilan groundstrokes tenis lapangan, (2) Perbedaan pengaruh antara persepsi kinestetik terhadap keterampilan groundstrokes tenis lapangan, dan (3) interaksi metode latihan dan persepsi kinestetik terhadap keterampilan groundstrokes. Penelitian ini merupakan penelitian eksperimen. Populasi penelitian adalah siswa SD Negeri Petinggen dan SD Negeri Terbansari yang berjumlah 75 siswa. Sampel penelitian 40 siswa ditentukan dengan teknik purposive sampling. Pengumpulan data menggunakan tes persepsi kinestetik dan keterampilan groundstrokes. Instrumen dalam penelitian ini adalah horizontal liner space test dan memantulakan bola ke dinding. Teknik analisis data menggunakan ANAVA. Hasil penelitian adalah: (1) ada perbedaan pengaruh yang signifikan antara metode demonstrasi dan audio visual terhadap keterampilan groundstrokes tenis lapangan (2) ada perbedaan yang signifikan keterampilan groundstrokes tenis lapangan antara siswa yang memiliki persepsi kinestetik tinggi dan rendah, dan (3) ada interaksi yang signifikan antara metode latihan dan persepsi kinestetik terhadap hasil groundstrokes tenis lapangan.
\end{abstract}

Kata Kunci: demonstrasi, audio visual, persepsi kinestetik, groundstrokes tenis lapangan.

\section{THE EFFECT OF TRAINING METHOD AND KINESTHETIC PERCEPTION GROUNDSTROKE SKILLS OF ELEMENTARY SCHOOL STUDENTS IN TENNIS}

\begin{abstract}
This study aims to investigate: (1) the difference between the effect of audio-visual methods and the demonstration of the skills of tennis courts groundstrokes, (2) the difference between the effect of kinesthetic perception of the skill of tennis courts groundstrokes, and (3) the interaction of exercise and kinesthetic perception of the skills tennis courts of groundstrokes. This study is experimental. The study population is students Petinggen Elementary School and Elementary School Terbansari totaling 75 students. The research sample of 40 students is determined by purposive sampling technique. Collecting data using kinesthetic perception tests and skills groundstrokes. The instrumen in this study is a horizontal linear space test and memantulakan balls to the wall. Analysis using ANOVA results show that: (1) no significant difference between the methods and audio-visual demonstration of the skills of tennis groundstrokes (2) there are significant differences between the tennis groundstrokes skills of students who have a kinesthetic perception of high and low, and (3) thereis a significant interaction between training methods and kinesthetic perception of the results of tennis groundstrokes.
\end{abstract}

Keywords: demonstration, audio visual, kinesthetic perception, tennis groundstrokes.

How to Cite: Suryono, S. (2016). Pengaruh metode latihan dan persepsi kinestetik terhadap keterampilan groundstrokes tenis lapangan pada siswa SD. Jurnal Keolahragaan, 4(2), $220 \quad-\quad 231$. doi:http://dx.doi.org/10.21831/jk.v4i2.10901

Permalink/DOI: http://dx.doi.org/10.21831/jk.v4i2.10901 


\section{PENDAHULUAN}

Tenis lapangan telah memasyarakat dan tidak lagi merupakan permainan yang hanya dilakukan oleh kalangan atas saja. Tenis lapangan dengan pesat telah menjadi olahraga yang sangat digemari di Indonesia pada khususnya dan di internasional pada umumnya. Hal ini terbukti dengan semakin banyaknya berdiri klub tenis lapangan yang ada sekarang. Meskipun telah menjadi olahraga yang terkenal di Indonesia prestasi atlet-atlet tenis lapangan Indonesia belum menunjukkan hasil yang baik, terbukti tenis Indonesia belum bisa menunjukkan prestasi memuaskan di Internasional. Hal tersebut merupakan tugas dan tanggung jawab pembina, pelatih atau orang yang berkecimpung dalam dunia tenis lapangan. Fenomena ini hendaknya menjadi dasar untuk dapat memberikan pembinaan secara intensif terhadap atlit tenis Indonesia. Berbagai upaya pembinaan atlit dilaksanakan di seluruh perkotaan dan kabupaten hingga saat ini. Salah satu contoh di Kabupaten Bantul Yogyakarta upaya yang dilakukan yaitu dengan memberikan pembinaan pada atlit berbakat sejak usia dini. Faktor lain yang dapat mengoptimalkan pencapaian prestasi dalam tenis lapangan yakni dengan diselenggarakan kegiatan ekstrakurikuler tenis lapangan dari tingkat Sekolah Dasar sampai dengan Sekolah Menengah Atas. Pembinaan ini bertujuan untuk menyiapkan atlit berbakat agar mampu meningkatkan prestasi tenis lapangan Indonesia.

Oleh karena itu, usia dalam pembibitan olahragawan adalah orang yang masih muda, objek pemasalan dan pembinaan adalah kelompok pelajar di sekolah dasar, yang usia rata-rata anak sekolah dasar yaitu 6-13 tahun. Usia untuk memulai latihanolahraga, khususnya permainan tenis diajarkan pada usia 6-8 tahun. Menurut Sukadiyanto (2003, p.10) permainan tenis pada usia 7-9 tahun merupakan waktu yang baik untuk latihan dasar dan pada usia 10-12 tahun waktu untuk belajar keterampilan yang baru. Pada latihan dasar (usia7-9 tahun) tujuannya adalah untuk memberikan bekal pengayaan keterampilan gerak dasar bagi para calon petenis atau merupakan tahap multi lateral training. Sedangkan usia 10-12 tahun merupakan usia yang baik untuk mulai belajar keterampilan khusus dan teknik-teknik pukulan tenis.

Tujuan permainan tenis lapangan adalah berusaha untuk menjatuhkan bola di daerah permainan lawan dan berusaha agar lawan tidak dapat memukul bola.

Mundaru (2006, p.5) menyatakan tujuan orang bermain tenis antara lain adalah untuk mendapatkan kesenangan, memenuhi hasrat bergerak, memelihara kesehatan tubuh dan untuk mencapai prestasi. Prinsip dasar bermain tenis adalah memukul bola sebelum atau sesudah mantul di lapangan dengan menggunakan raket, melewati di atas net dan masuk ke dalam lapangan permainan lawan (Sukadiyanto, 2003, p.14). Sedangkan teknik untuk memukul bola agar melewati net dan masuk ke daerah lawan yaitu servis, groundstrokes, voli, lob, dan smes. Senada dengan Sudiro (2008, p.4) teknik-teknik dasar dalam permainan tenis dapat dikelompokkan menjadi teknik groundstrokes, service, volley, lob dan smash. Soediharso (2001, p.4) menambahkan $88 \%$ jenis pukulan yang dilakukan dalam permainan tenis adalah groundstrokes, yaitu merupakan pukulan yang dilakukan setelah bola memantul dari lantai. Karena teknik groundstrokes dominan dalam permainan tenis.

Sukadiyanto (2004, p.26) menyatakan hampir semua orang yang baru belajar bermain tenis mengalami kesulitan, sehingga permainan tenis seringkali digolongkan ke dalam jenis keterampilan yang sulit dan kompleks. Kondisi lingkungan bermain tenis (pukulan bola lawan) sulit dikendalikan atau sulit diperkirakan sebelumnya oleh petenis. Hal tersebut dikarenakan petenis memukul bola yang tidak konstan maksudnya dalam hal arah, jenis putaran, ketinggian, kecepatan serta jarak jatuhnya bola yang sulit diperkirakan sebelumnya. Menurut Bornemann, et al (2000, pp.34-37) ada beberapa pegangan grip yang dikenal untuk pukulan forehand yaitu eastern, western dan continental. Eastern forehand grip merupakan cara meme-gang raket pada lehernya dengan tangan kiri kemudian seperti berjabat tangan dan posisi telapak tangan kanan di belakang pegangan serta jari-jari ditempelkan melingkari pegangan raket. Western forehand grip adalah suatu cara memegang raket dengan tangan kiri memegang pada lehernya kemudian meletakkan telapak tangan kanan di bawah pegangan raket dan bungkuskan jari-jari mengelilingi pegangan raket. Continental forehand grip yaitu cara memegang raket pada lehernya dangan tangan kiri kemudian tangan kanan memegang raket seperti huruf $\mathrm{V}$ antara ibu jari dengan telunjuk dan lipatkan jari-jari tangan mengelilingi pegangan raket. Ada dua cara memegang raket 
pada pukulan backhand yaitu eastern backhand grip dan two handed backhand grip (Bornemann, et al, 2000, pp.35-37). Eastern backhand grip dimulai dengan eastern forehand grip kemudian gerakkan tangan seperempat putaran pada bagian atas pegangan dengan ibu jari terletak miring pada bagian belakang pegangan, genggam raket dengan kuat dan taruh tangan kiri pada leher raket sampai mulai mengayun ke depan. Two handed backhand grip yaitu cara memegang raket menggunakan dua tangan dengan tangan utama dekat dengan ujung pegangan raket atau yang paling dekat dengan tubuh. Brown (2001, p.13) teknik groundstrokes adalah memukul bola setelah mantul dari lapangan permainan. Artinya semua jenis pukulan yang dilakukan setelah bola mantul dari lapangan terlebih dahulu termasuk dalam kelompok teknik groundstrokes. Adapun teknik groundstrokes terdiri atas forehand groundstrokes dan backhand groundstrokes.

Teknik pukulan yang pertama kali diajarkan kepada para pemula yang baru belajar permainan tenis adalah forehand groundstrokes. Selanjutnya Brown (2001, p.27) menyatakan bahwa forehand groundstrokes juga merupakan pukulan yang dominan dilakukan para petenis karena dengan teknik itu mampu memberikan rasa percaya diri kepada petenis. Pada dasarnya teknik forehand groundstrokes memiliki konsep dasar gerakan yang sama dengan backhand groundstrokes, karena gerakan backhand groundstrokes merupakan kebalikan dari gerakan forehand groundstrokes. Karena faktor kebiasaan atau keterlatihan dalam melakukan kegiatan sehari-hari menyebabkan orang lebih mudah untuk beradaptasi dengan gerakan forehand groundstrokes. Namun dalam mengajarkan kedua teknik baik forehand maupun backhand sebaiknya dilatihkan secara seimbang dalam tiap pertemuan sehingga berimbang antara tubuh bagian kanan dan kiri. Orang lebih mudah untuk beradaptasi dengan gerakan forehand karena faktor kebiasaan yang dilakukan dalam kehidupan sehari-hari. Hal ini dijelaskan oleh Sukadiyanto (2003, p.42) teknik forehand dirasakan lebih mudah, meskipun gerakannya tidak alamiah, karena pengaruh dari gerakan sehari-hari seperti melempar, menangkap, dan memukul merupakan gerakan yang sama dengan gerakan teknik forehand. Konsep dasar teknik forehand yaitu telapak tangan menghadap arah datangnya bola. Selain itu, otot yang digunakan saat melakukan teknik forehand yaitu otot lengan bagian depan. Jadi pengertian forehand groundstrokes yaitu teknik pukulan untuk mengembalikan bola yang dilakukan setelah bola mantul di lapangan, dengan mengayun raket ke depan menggunakan otot lengan bagian depan serta telapak tangan mengahadap ke depan.

Penampilan keterampilan gerak melalui proses pembelajaran maupun latihan dapat bersifat positif maupun negatif. Artinya positif, keterampilan gerak yang dimiliki akan bertambah baik dan benar. Sebaliknya yang negatif, keterampilan gerak yang dimiliki tidak bertambah baik dan tidak benar. Hal ini disebabkan oleh kesalahan-kesalahan yang terjadi selama proses latihan tidak mendapatkan koreksi dan bimbingan tentang gerak yang benar dan baik. Oleh karena itu diperlukan koreksi dan bimbingan atau umumnya dinamakan umpan balik (feed back) dan balikan informatif. Upaya untuk meningkatkan keterampilan gerak dilakukan melalui proses latihan yang dilakukan secara kontinyu, progresif, dan berkelanjutan. Latihan adalah penerapan dari suatu perencanaan untuk meningkatkan kemampuan berolahraga yang berisikan materi teori dan praktek, metode, dan aturan pelaksanaan sesuai dengan tujuan dan sasaran yang akan dicapai Sukadiyanto (2002, p.7). Selain itu, latihan merupakan upaya yang dilakukan seseorang untuk mempersiapkan diri dalam upaya untuk mencapai tujuan tertentu. Dalam istilah fisiologis, latihan adalah upaya seseorang dalam meningkatkan perbaikan sistem organisme dan fungsinya untuk mengoptimalkan prestasi dan penampilan olahraga.

Selama proses belajar atau latihan, ketepatan pelatih dalam menerapkan metode sangat menentukan keberhasilan dalam mencapai tujuan yang diinginkan. Belajar adalah tahapan perubahan seluruh tingkah laku individu yang relatif menetap sebagai hasil pengalaman dan interaksi dengan lingkungan yang melibatkan proses kognitif. Proses pembelajaran itu sendiri menekankan pada terjadinya interaksi antara peserta didik, guru, metode, kurikulum, sarana, dan aspek lingkungan yang terkait untuk mencapai kompetensi pembelajaran. Kompetensi akan tercapai dengan maksimal ketika semua komponen terpenuhi sesuai dengan fungsinya masing-masing.

Keberhasilan pembelajaran dipengaruhi oleh banyak faktor, baik faktor internal dari dalam diri siswa, maupun faktor eksternal yang berasal dari luar siswa. Sebagai salah satu faktor yang mempengaruhi belajar, minat adalah kecenderungan seseorang terhadap objek atau 
suatu kegiatan yang digemari yang disertai dengan perasaan senang, adanya perhatian dan keaktifan berbuat. Minat besar pengaruhnya terhadap hasil belajar siswa, bila bahan pelajaran yang dipelajari tidak sesuai dengan minat siswa, maka siswa tidak akan belajar dengan sebaik-baiknya karena tidak ada daya tarik baginya. Siswa yang tidak berminat terhadap suatu pelajaran tidak mempunyai perhatian terhadap apa yang diajarkan guru, siswa menjadi acuh, tidak mendengarkan penjelasan guru, bahkan ribut sendiri. Selain faktor minat, motivasi juga berpengaruh terhadap keberhasilan belajar siswa. Motivasi merupakan suatu perubahan yang terdapat dalam diri seseorang untuk melakukan sesuatu guna mencapai tujuan. Tujuan yang hendak dicapai siswa ini merupakan pendorong atau penyemangat bagi siswa untuk lebih giat belajar.

Dengan motivasi ini, siswa menjadi tekun dalam proses belajar mengajar, dan dengan motivasi pula kualitas hasil belajar siswa dapat diwujudkan dengan baik. Siswa yang mempunyai motivasi kuat dan jelas akan tekun dalam proses belajar mengajar dan akan berhasil dalam belajarnya. Selanjutnya, salah satu faktor eksternal yang sangat berpengaruh terhadap keberhasilan belajar adalah terletak pada guru. Metode mengajar yang digunakan oleh guru mempengaruhi belajar siswa. Cara menyajikan bahan pelajaran yang menarik akan membuat siswa tertarik untuk belajar, sedangkan metode mengajar yang kurang menarik akan mempengaruhi belajar siswa kurang tertarik. Hal ini guru harus kreyatif dalam pembelajaran untuk membangkitkan minat peserta didik (siswa) dengan melakukan berbagai strategi pembelajaran yang efektif. Beberapa strategi pembelajaran yang sering digunakan dalam proses belajar mengajar adalah metode demonstrasi, ceramah, media pembelajaran, dan metode lainnya. Dalam proses belajar untuk keterampilan groundstrokes tenis lapangan ini menggunakan metode demonstrasi dan audio visual, karena metode demonstrasi dan audio visual proses pembelajaran akan menarik minat belajar untuk siswa.

Penampilan keterampilan gerak melalui proses pembelajaran maupun latihan dapat bersifat positif maupun negatif. Artinya positif, keterampilan gerak yang dimiliki akan bertambah baik dan benar. Sebaliknya yang negatif, keterampilan gerak yang dimiliki tidak bertambah baik dan tidak benar. Hal ini disebabkan oleh kesalahan-kesalahan yang terjadi selama proses latihan tidak mendapatkan koreksi dan bimbingan tentang gerak yang benar dan baik. Oleh krena itu diperlukan koreksi dan bimbingan atau umumnya dinamakan umpan balik (feed back) dan balikan informatif. Upaya untuk meningkatkan keterampilan gerak dilakukan melalui proses latihan yang dilakukan secara kontinyu, progresif, dan berkelanjutan. Latihan adalah penerapan dari suatu perencanaan untuk meningkatkan kemampuan berolahraga yang berisikan materi teori dan praktek, metode, dan aturan pelaksanaan sesuai dengan tujuan dan sasaran yang akan dicapai Sukadiyanto (2003, p.7). Selain itu, latihan merupakan upaya yang dilakukan seseorang untuk mempersiapkan diri dalam upaya untuk mencapai tujuan tertentu. Dalam istilah fisiologis, latihan adalah upaya seseorang dalam meningkatkan perbaikan sistem organisme dan fungsinya untuk mengoptimalkan prestasi dan penampilan olahraga.

Model pembelajaran dapat diartikan sebagai suatu pola atau bentuk pembelajaran yang di dalamnya terdapat langkah-langkah pembelajaran untuk mempelajari suatu topik tertentu sesuai dengan tujuan belajar yang hendak dicapai. Selain itu juga terdapat lingkungan belajar yang dibutuhkan agar pembelajaran tersebut dapat berhasil. Rahyubi (2012, p.251) menyatakan bahwa model pembelajaran adalah kerangka konseptual yang digunakan sebagai pedoman dalam melakukan pembelajaran. Pembelajaran pada hakikatnya merupakan suatu proses interaksi antara guru dengan siswa, baik interaksi secara langsung maupun tidak langsung. Untuk itu dalam pelaksanaannya model pembelajaran dapat dijadikan pola pilihan, artinya para guru boleh memilih model pembelajaran yang sesuai dan efisien untuk mencapai tujuan pendidikannya.

Menurut Sumantri \& Permana (2001, p.133) metode demonstrasi diartikan sebagai cara penyajian pelajaran dengan memperagakan dan mempertunjukkan kepada peserta didik suatu proses, situasi atau benda tertentu yang sedang dipelajari baik dalam bentuk yang sebenarnya maupun dalam bentuk tiruan yang dipertunjukkan oleh guru atau sumber belajar lain yang memahami atau ahli dalam topik bahasa yang harus didemonstrasikan. Menurut Suyitno (2005, p.3) metode demonstrasi adalah cara penyapaian pelajaran dari seorang guru kepada siswa di dalam kelas atau di luar kelas dengan menonjolkan suatu kemampuan. Dari pendapat tersebut dapat diambil kesimpulan bahwa metode demonstrasi adalah suatu metode 
mengajar yang digunakan guru untuk memperagakan serta memperlihatkan suatu proses sesuai dengan materi yang diajarkan baik secara langsung maupun tidak langsung yang diikuti oleh murid agar pengetahuan dan keterampilan yang diajrkan dapat dipahami dan dikuasai oleh murid tersebut, persepsi merupakan suatu proses penginderaan, yaitu merupakan proses diterimanya stimulus oleh individu melalui alat indera atau juga disebut proses sensoris. Namun proses itu tidak berhenti begitu saja, melainkan stimulus tersebut diteruskan dan proses selanjutnya merupakan proses persepsi. Karena itu proses persepsi tidak dapat lepas dari proses penginderaan merupakan proses pendahulu dari proses persepsi. Persepsi merupakan proses yang integrated dalam diri individu terhadap stimulus yang diterimanya.

Dengan demikian dapat dikemukakan bahwa persepsi itu merupakan pengorganisasian, penginterpretasian terhadap stimulus yang diinderanya sehingga merupakan sesuatu yang berarti, dan merupakan respon yang integrated dalam diri individu. dengan persepsi individu akan menyadari tentang keadaan di sekitarnya dan juga keadaan diri sendiri. Persepsi adalah proses yang menyangkut masuknya pesan atau informasi ke dalam otak manusia. Melalui persepsi manusia terus-menerus mengadakan hubungan dengan lingkungannya. Hubungan ini dilakukan lewat inderanya, yaitu indera penglihat, pendengar, peraba, perasa, dan pencium.

Keterampilan adalah kemampuan seseorang dalam menggunakan pengetahuannya secara efektif dan siap untuk menampilkan gerak. Keterampilan yang didemonstrasikan dalam penampilan merupakan pertanda dari segala sesuatu yang telah dipelajari (Hariono, 2008, p.79). Menguasai keterampilan teknik groundstrokes perlu melalui proses gerak sebelumnya. Anak sering mengalami kesulitan dalam mempraktekkan gerakan karena belum memiliki gambaran gerak atau rencana pelaksanaannya. Tingkat keberhasilan seseorang dalam mempelajari suatu keterampilan gerak yang baru, dapat dilihat dari kemampuan penampilannya. Keterampilan adalah kecakapan yang telah dicapai atau dilakukan. Pencapaian kemampuan atau kecakapan dapat diperoleh melalui proses belajar. Dengan demikian keterampilan adalah hasil belajar yang diperoleh setelah seseorang mengikuti proses belajar atau latihan.

Menurut Sukadiyanto (2003, p.30) penggolongan petenis pemula dapat dibedakan menjadi dua hal yaitu (1) berdasarkan tingkat keterampilan, dan (2) berdasarkan usia. Dimaksudkan pemula berdasar tingkat keterampilan adalah seseorang yang belum pernah memiliki keterampilan tenis berapapun usia yang dimilikinya, sedangkan pemula berdasarkan usia adalah orang belajar keterampilan tenis yang masih usia muda.

\section{METODE}

Penelitian ini adalah penelitian eksperimen yang bertujuan untuk membandingkan dua perlakuan yang berbeda pada subjek penelitian. Adapun jenis penelitian yang digunakan dalam penelitian ini adalah eksperimen dengan desain faktorial $2 \times 2$, dengan menggunakan tes awal (pretest) dan tes akhir (posttest). Menurut Sudjana (2002, p.148) eksperimen faktorial adalah eksperimen yang hampir semua faktor dikombinasikan atau disilangkan dengan tiap faktor lainnya yang ada dalam eksperimen. Rancangan penelitian dapat selengkapnya dapat dilihat pada Tabel 1 .

Tabel 1. Desain Penelitian Faktorial 2 x 2

\begin{tabular}{ccc}
\hline $\begin{array}{c}\text { Variabel } \\
\text { Manipulatif }\end{array}$ & \multicolumn{2}{c}{ Metode Pembelajaran } \\
\cline { 1 - 1 } $\begin{array}{c}\text { Persepsi } \\
\text { Kinestetik }\end{array}$ & $\begin{array}{c}\text { Demonstrasi } \\
(\mathbf{A 1})\end{array}$ & $\begin{array}{c}\text { Audio } \\
\text { visiual } \\
(\mathbf{A 2})\end{array}$ \\
\hline Tinggi $\left(\mathrm{B}_{1}\right)$ & $\mathrm{A}_{1} \mathrm{~B}_{1}$ & $\mathrm{~A}_{2} \mathrm{~B}_{1}$ \\
Rendah $\left(\mathrm{B}_{2}\right)$ & $\mathrm{A}_{1} \mathrm{~B}_{2}$ & $\mathrm{~A}_{2} \mathrm{~B}_{2}$ \\
\hline
\end{tabular}

Keterangan:

$\mathrm{A}_{1} \mathrm{~B}_{1}$ : Kelompok siswa yang memiliki persepsi kinestetik tinggi dilatih menggunakan demonstrasi.

$\mathrm{A}_{2} \mathrm{~B}_{1}$ : Kelompok siswa yang memiliki persepsi kinestetik tinggi dilatih menggunakan audio visiual.

$\mathrm{A}_{1} \mathrm{~B}_{2}$ : Kelompok siswa yang memiliki persepsi kinestetik rendah dilatih menggunakan demonstrasi.

$\mathrm{A}_{2} \mathrm{~B}_{2}$ : Kelompok siswa yang memiliki persepsi kinestetik rendah dilatih menggunakan audio visiual.

Hasil eksperimen yang menggunakan desain faktorial akan memperoleh informasi tetang kontribusi masing-masing variable independen terhadap hasil perlakuan dan interaksi di antara variable-variabel yang dilibatkan. Kelebihan menggunakan penelitian eksperimen desain faktorial adalah kemampuan untuk memperoleh informasi mengenai interaksi di antara variable-variabel independen yang mempengaruhi variable dependen. 


\section{Waktu dan Tempat Penelitian}

Penelitian ini dilaksanakan di SD Negeri Petinggen Yogyakarta dan SD Negeri Terbansari 1 Yogyakarta. Waktu pelaksanaan penelitian yaitu berlangsung pada bulan DesemberFebruari. Pada hari Senin, Selasa, dan Rabu untuk kelompok A1B1 dan A1B2 dengan 1 kali pre-test, 16 kali latihan dan 1 kali posttest. Latihan dimulai pada pukul 16.00 - 18.00 WIB. Pelaksanaan latihan agak sedikit berbeda pada kelompok A2B1 dan A2B2 dengan hari latihan Kamis, Jum'at, dan Sabtu. Penelitian ini dibagi menjadi 4 kelompok perlakuan program latihan groundstrokes tenis lapangan, kelompok 1 metode demonstrasi dengan persepsi kinestetik tinggi mengunakan (A1B1) dipandu oleh seorang pelatih dilaksanakan di SD Negeri Petinggen Yogyakarta, kelompok 2 metode audio visual dengan persepsi kinestetik tinggi (A2B1) dipandu oleh seorang pelatih dilaksanakan di SD Negeri Petinggen Yogyakarta, Kelompok 3 metode demonstrasidengan persepsi kinestetik rendah (A1B2) dipandu oleh seorang pelatih dilaksanakan di SD Negeri Terbansari 1 Yogyakarta, dan kelompok 4 metode audio visual dengan persepsi kinestetik rendah (A2B2) dipandu oleh seorang pelatih dilaksanakan di SD Negeri Terbansari 1 Yogyakarta. Dalam pelaksanaan program latihan, pelatih atau guru ditempatkan di sekolah masing-masing. Spesifikasi penentuan metode latihan dari kedua SD tersebut mengunakan ordinal pairing. Menggunakan nomor urut persepsi kinestetik dengan cara angka ganjil genap, maka dapat disimpulkan bahwa angka ganjil yaitu urutan 1, 3, 5, 7 , dan seterusnya mengikuti kelompok demonstrasi selanjutnya angka genap yaitu 2, 4, 6, 8, dan seterusnya menempati kelompok audio visual.

\section{Populasi dan Sampel Penelitian}

Menurut Azwar (2010, p.77) Populasi didefinisikan sebagai kelompok subjek yang hendak dikenai generalisasi hasil penelitian. Populasi pada penelitian ini adalah siswa kelas IV SD Negeri Petinggen Yogyakarta dan siswa kelas IV SD Negeri Terbansari 1 Yogyakarta. Menurut Nanang (2012, p.74) sampel adalah merupakan bagian dari populasi yang memiliki ciri-ciri atau keadaan tertentu yang akan diteliti penelitian ini adalah siswa kelas IV SD Negeri Petinggen Yogyakarta dan SD Negeri Terbansari 1 Yogyakarta.
Adapun teknik pengambilan sampel dalam penelitian ini adalah dengan cara purposive sampling. Berdasarkan teori diatas, maka sampel yang diambil adalah siswa kelas IV SD Negeri Petinggen Yogyakarta dan SD Negeri Terbansari 1 Yogyakarta. Besar sampel yang akan digunakan dalam penelitian ini adalah $27 \%$ batas atas dan $27 \%$ batas bawah setelah dilakukan tes persepsi kinestetik pada populasi (Miller, 2002, p.68). Dari jumlah populasi yang diambil menjadi sampel harus memiliki ketentuan-ketentuan untuk memenuhi tujuan penelitian. Ketentuan-ketentuan tersebut adalah: (a) siswa kelas IV SD, (b) Berminat dan bersedia mengikuti latihan groundstrokes tenis lapangan sebanyak 16 kali pertemuan, 1 kali pre tes, dan 1 kali pos tes, (c) Sehat jasmani dan rohani, (d) belum pernah bermain tenis, dan (e) Sampel dinyatakan gugur jika 2 kali berturut-turut tidak mengikuti latihan. Karena jika anak latih tidak mengikuti latihan selama $2 \times 24$ jam maka kondisi tubuh dalam menerima rangsang kembali ke semula atau latihan mulai dari awal.

Dari 40 siswa yang memiliki presepsi kinestetik tinggi tadi diambil 10 siswa diberi perlakuan dengan metode demonstrasi dan 10 siswa diberi perlakuan metode audio visual. Demikian pula dengan siswa yang memiliki presepsi kinestetik rendah diperlakukan dengan cara yang sama. Dari 40 siswa setelah dilakukan pretest dipisahkan menjadi 2 kelompok yang seimbang. Pengelompokan yang seimbang menggunakan ordinal pairing. Sampel yang memiliki kemampuan setara dipasangkan, kemudian anggota tiap pasangan dipisah dalam dua kelompok eksperimen didasarkan pada kemampuan presepsi kinestetik pada saat pretest. Setelah hasil awal diranking kemudian subjek yang memiliki kemampuan dipasangkan ke dalam kelompok 1 (K 1, keterampilan groundstrukes metode demonstrasi) dan dalam kelompok 2 (K 2, keterampilan groundstrukes dengan metode audio visual). Dengan demikian kedua kelompok tersebut diberi perlakuan yang berbeda dan pada akhirnya terdapat perbedaan perlakuan yang diberikan. Berdasarkan hal tersebut didapat 20 siswa yang memiliki persepsi kinestetik tinggi dan 20 siswa yang memiliki presepsi kinestetik rendah. Kelompok siswa yang memiliki presepsi kinestetik tinggi dan presepsi kinestetik rendah masing-masing dibagi menjadi dua kelompok dengan cara ordinal pairing, yaitu 20 siswa mendapat metode demonstrasi dan 20 siswa mendapat metode audio visual. Jadi, besar sampel dalam peneliti- 
an ini adalah 40 siswa yang terdiri atas 20 siswa yang memiliki presepsi kinestetik tinggi dan 20 siswa yang memiliki presepsi kinestetik rendah. Adapun teknik pembagian kelompok dengan ordinal pairing menurut Sutrisno Hadi dalam Dinata, Sutardji, \& Waluyo (2013, p.26) seperti pada Gambar 1.

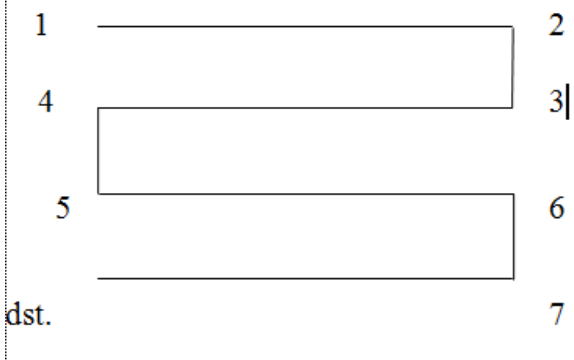

Gambar 1. Pembagian Kelompok dengan Ordinal Pairing

Jumlah sampel minimal untuk penelitian dengan eksperimen adalah 10 subjek tiap kelompok (Balnaves dan Caputi, 2001, p.94). Dalam penelitian ini terdapat 20 subjek tiap kelompok, jadi total sampel dalam penelitian ini 40. Adapun komposisi anggota sampel untuk masing-masing sel seperti yang disajikan kemudian dimasukkan nilainya pada Tabel 3.

Tabel 2.Komposisi Anggota Sampel Menurut Perlakuan

\begin{tabular}{ccc}
\hline $\begin{array}{c}\text { Metode } \\
\text { Pembelajaran }\end{array}$ & $\begin{array}{c}\text { Demonstrasi } \\
\left(\mathbf{A}_{\mathbf{1}}\right)\end{array}$ & Audio Visual $\left(\mathbf{A}_{\mathbf{2}}\right)$ \\
\hline Tinggi $\left(\mathrm{B}_{1}\right)$ & 10 & 10 \\
Rendah $\left(\mathrm{B}_{2}\right)$ & 10 & 10 \\
\hline
\end{tabular}

Berdasarkan Tabel 2 terdapat empat kelompok komposisi anggota sampel menurut perlakuan yaitu siswa yang dilatih dengan metode demonstrasi $\left(\mathrm{A}_{1}\right)$ dan memiliki persepsi kinestetik tinggi $\left(B_{1}\right)$ sejumlah 10 siswa. Kedua siswa yang dilatih dengan metode audio visual $\left(\mathrm{A}_{2}\right)$ dan memiliki persepsi kinestetik tinggi $\left(B_{1}\right)$ sejumlah 10 siswa. Ketiga, siswa yang dilatih dengan metode audio visual $\left(\mathrm{A}_{2}\right)$ dan memiliki persepsi kinestetik rendah $\left(\mathrm{B}_{2}\right)$ sejumlah 10 siswa. Keempat, siswa yang dilatih dengan metode demonstrasi $\left(\mathrm{A}_{1}\right)$ dan memiliki persepsi kinestetik rendah $\left(\mathrm{B}_{2}\right)$ sejumlah 10 siswa. Jumlah keseluruhan sampel dalam penelitian ini ada 40 siswa.

\section{Variabel Penelitian}

Penelitian ini melibatkan dua variable bebas yang dimanipulasi, satu variable bebas yang dikendalikan (atribut), satu variable terikat dan satu variable moderator. Variable bebas yang dimanipulasi terdiri atas: (1) metode demonstrasi dan (2) metode audio visual. Metode demonstrasi merupakan metode cara penyapaian pelajaran dari seorang guru kepada siswa di dalam kelas atau di luar kelas dengan menonjolkan suatu kemampuan. Metode audio visual merupakan media yang mempunyai unsur suara dan unsur gambar.

Variable bebas yang dikendalikan (atribut) adalah persepsi kinestetik, yang terdiri atas (1) persespsi kinestetik tinggi dan (2) persespsi kinestetik rendah. Persepsi kinestetik merupakan salah satu unsur penting bagi gerakan aktivitas olahraga. Persepsi kinestetik berkenaan dengan kemampuan seseorang untuk menyadari posisi dan gerak yang telah dilakukan. Variable terikat adalah keterampilan groundstrokes tenis lapangan. Groundstrokes adalah teknik dasar memukul bola bawah setelah mantul di lapangan baik dari sebelah kanan maupun dari sebelah kiri pemain agar melewati net dan masuk daerah lawan.

\section{Teknik Instrumen Pengumpulan Data}

Prinsip suatu penelitian adalah melakukan pengukuran dan harus ada alat ukur yang baik. Alat ukur dalam penelitian seperti yang dikemukakan oleh Sugiyono (2007, p.102) instrumen penelitian adalah suatu alat yang digunakan untuk mengukur fenomena alam maupun sosial yang diamati, secara sepesifik semua fenomena itu disebut variable penelitian. Instrumen penelitian secara garis besar bisa digolongkan menjadi dua, yaitu berbentuk tes dan non tes, sesuai dengan penelitian ini menggunakan tes. Mengenai tes adalah serentetan pertanyaan atau latihan serta alat lain yang digunakan untuk mengukur keterampilan, pengetahuan inteligensi, kemampuan atau bakat yang dimiliki oleh individu atau kelompok. Adapun instrumen penelitian yang digunakan dalam penelitian ini adalah tes persepsi kinestetik menggunakan horizontal liner space test dan keterampilan groundstrokes tenis lapangan memantulkan bola ke dinding.

\section{Teknik Analis Data}

Setelah data keterampilan groundstrokes tenis lapangan dan persepsi kinestetik, langkah selanjutnya adalah mengolah dan menganalisis data tersebut.Pada bagian ini akan diuraikan mengenai teknik analisis data hasil tes, terhadap metode demonstrasi dan audio visual. Teknik analisis data yang digunakan adalah teknik analisis varian (anava) dua jalur pada $\alpha=5 \%$. Jika 
F yang diperoleh $\left(\mathrm{F}_{0}\right)$ signifikan analisis dilanjutkan dengan uji perbedaan seluruh kelompok dan antar dua kelompok yaitu dengan uji $t$ dan anava dua jalur. Untuk memenuhi asumsi dalam teknik anava, maka sebelumnya dilakukan uji normalitas dengan uji kolmogorov smirnow dan uji homogenitas varians menggunakan uji bartlett. Untuk menguji hipotesis dilakukan dengan menggunakan ANOVA dua jalur dan apabila terbukti terdapat interaksi maka akan dilakukan uji lanjutan yaitu uji pairwise comparisons.

\section{HASIL DAN PEMBAHASAN}

Dari hasil penelitian menunjukkan bahwa ada perbedaan pengaruh antara metode pembelajaran terhadap keterampilan groundstrokes tenis lapangan siswa SD Yogyakarta. Hal ini menunjukkan bahwa nilai signifikansi Univariate Tests sebesar 0,00 dengan $\mathrm{F}_{\text {hitung }} 62.921$ yang lebih kecil dari taraf signifikan. Artinya ada pengaruh metode pembelajaran terhadap keterampilan grondstrokes tenis lapangan siswa SD Yogyakarta. Berarti bahwa metode demonstrasi dan audio visual memiliki pengaruh yang berbeda. Dari analisis lanjutan diperoleh bahwa ternyata metode demonstrasi memiliki peningkatan yang lebih baik daripada metode latihan audio visual, dengan rata-rata peningkatan masing-masing yaitu metode latihan demonstrasi 10.800 dan metode latihan audio visual sebesar 7.350. Dengan demikian metode demonstrasi lebih bagus daripada metode audio visual pada masa sebelum retensi, sebagai hasil fase latihan.

Dari hasil penelitian menunjukkan bahwa ada perbedaan pengaruh antara persepsi kinestetik terhadap keterampilan groundstrokes tenis lapangan siswa SD Yogyakarta. Hal ini menunjukkan bahwa dari nilai signifikansi Univariate Tests sebesar 0,021 dengan $\mathrm{F}_{\text {hitung }} 5.828$ yang lebih kecil dari taraf signifikan. Artinya ada pengaruh persepsi kinestetik terhadap keterampilan grondstrokes tenis lapangan siswa SD Yogyakarta.Berarti bahwa siswa yang memiliki persepsi kinestetik tinggi memiliki peningkatan yang berbeda. Dari analisis lanjutan diperoleh bahwa ternyata siswa yang memiliki persepsi kinestetik tinggi memiliki peningkatan yang lebih baik daripada siswa yang memiliki persepsi kinestetik rendah, dengan rata-rata peningkatan masing-masing yaitu siswa yang memiliki persepsi kinestetik tinggi 8.550 dan siswa yang memiliki persepsi kinestetik rendah sebesar 9.600. Dengan demikian siswa yang memiliki persepsi kinestetik tinggi lebih bagus daripada siswa yang memiliki persepsi kinestetik rendah pada masa sebelum retensi, sebagai hasil fase latihan.

Dari hasil penelitian menunjukkan bahwa Ada interaksi antara metode pembelajaran dan persepsi kinestetik terhadap keterampilan groundstrokes tenis lapangan siswa kelas IV SD Negeri Petinggen Yogyakarta dan SD Negeri Terbansari 1 Yogyakarta. Hal ini dibuktikan bahwa taraf signifikansi sebesar 0,00 dengan $\mathrm{F}_{\text {hitung }}$ 91.749. Hal ini menunjukkan bahwa tingkat signifikansi 5\% ada interaksi antara metode pembelajaran dan persepsi kinestetik terhadap hasil keterampilan groundstrokes. Berdasrkan pengujian telah dihasilkan pembahasan sebagai berikut:

\section{Perbedaan Pengaruh Antara Latihan Demonstrasi dan Audio visual terhadap Hasil Keteram-pilan Groundstrokes.}

Berdasarkan pengujian hipotesis pertama ternyata ada perbedaan pengaruh yang nyata antara kelompok siswa yang mendapatkan metode demonstrasi yang diterapkan pada SD Negeri Petinggen Yogyakarta dan audio visual yang diterapkan di SD Negeri 1 Terbansari Yogyakarta. Pada kelompok siswa yang dilatih dengan demonstrasi mempunyai peningkatan hasil keterampilan groundstrokes lebih baik jika dibandingkan dengan siswa yang diberikan audio visual. Hal ini metode demonstrasi langsung dari seorang guru kepada siswa di dalam kelas atau di luar kelas dengan memperagakan suatu kemampuan.

Metode demonstrasi siswa secara langsung memperhatikan dan memperagakan bahan yang diperaktekkan oleh guru dan secara langsung memperagakan keterampilan groundstrokes, hal ini guru membimbing siswa ke arah berpikir yang sama dalam satu saluran pikiran yang sama. Proses penerimaan siswa terhadap pelajaran akan lebih berkesan secara mendalam, sehingga membentuk pengertian dengan baik dan sempurna. Siswa dapat mengamati, memperagakan dan memperhatikan gerakan selama pelajaran berlangsung. Menurut Suyitno (2005, p.3) metode demonstrasi adalah cara penyampaian pelajaran dari seorang guru kepada siswa di dalam kelas atau di luar kelas dengan menonjolkan suatu kemampuan.

Audio visual merupakan salah satu bentuk media pembelajaran yang diterapkan oleh guru ke siswa. Media audio visual adalah media pembelajaran yang pemanfaatannya untuk dili- 
hat dan didengar dan mempunyai unsur suara dan unsur gambar (Arsyad, 2009, p.36). Siswa dapat memahami meteri pembelajaran dengan indera pendengaran dan penglihatan sekaligus. Oleh karena itu, dengan media ini guru dapat menyuguhkan pengalaman-pengalaman yang konkrit kepada siswa yang sulit jika materi tersebut diajarkan. Tujuan menggunakan media adalah untuk melengkapi dan membantu guru dalam menyampaikan materi atau informasi. Menggunakan media audio visual dalam pembelajaran groudstrokes sangat mendukung siswa untuk lebih giat belajar dan dapat mempermudah mempelajari pesan atau pelajaran, membangkitkan semangat siswa, dan mempermudah guru dalam menyampaikan pesan atau pelajaran serta meningkatkan motivasi siswa. Begitu juga dengan tujuan guru menggunakan media audio visual adalah guru harus memandang media pendidikan sebagai alat bantu utama untuk menunjang keberhasilan belajar dan memperkembangkan metode-metode yang dipakainya dengan memanfaatkan media tersebut yaitu media audio visual yang merupakan bentuk media pengajaran yang terjangkau. Tugas guru di sini adalah mengajar, mendidik, melatih, dan mengevaluasi.

Kedua metode tersebut mempunyai beberapa kelebihan masing-masing dan kesamaan dalam menstimulasi indera peserta didik yaitu indera penglihatan dan indera pendengaran pada waktu proses penyampaian informasi. Perbedaannya pada nyata dan tidak nyata materi yang disampaikan. Pada metode demonstrasi peserta didik dapat berinteraksi langsung dengan pendidik tetapi pada metode audio visual hanya melihat rekaman video sehingga komunikasi yang terjadi hanya satu arah.

Persepsi kinestetik tinggi akan mudah melakukan keterampilan groundstrokes sedangkan bagi siswa yang memiliki persepsi kinestetik rendah akan mengalami kesulitan keterampilan groundstrokes. Berdasarkan kajian di atas, tampak bahwa metode demonstrasi lebih baik daripada audio visual. Kebenaran teori di atas juga diperkuat dengan hasil analisis data dalam penelitian ini yaitu: metode demonstrasi memiliki peningkatan rata-rata sebesar 10,800. Sedangkan metode audio visual memiliki peningkatan rata-rata sebesar 7,350. Dapat disimpulkan bahwa metode demonstrasi lebih baik jika dibandingkan dengan metode audio visual terhadap hasil keterampilan groundstrokes. Ini dikarenakan metode demonstrasi perhatian siswa akan dapat terpusat sepenuhnya pada pokok bahasan yang akan didemonstrasikan, memberikan pengalaman praktis yang dapat membentuk ingatan yang kuat dan keterampilan dalam berbuat, menghindarkan kesalahan siswa dalam mengambil suatu kesimpulan, karena siswa mengamati secara langsung jalannya demonstrasi yang dilakukan.

\section{Perbedaan Pengaruh Antara Persepsi Kinestetik Tinggi dan Rendah terhadap Hasil Keterampilan Groundstrokes.}

Persepsi kinestetik memiliki peran penting terhadap hasil keterampilan groundstrokes. Persepsi kinestetik dalam hal ini di mana tingkat kualitas persepsi kinestetik sesorang akan berpengaruh terhadap komponen-komponen biomotor yang lainnya. Persepsi kinestetik adalah kemampuan seseorang dalam mengintegrasikan antara posisi dan gerakan mata (pandangan) dengan gerakan tangan secara efektif. Persepsi kinestetik adalah berkenan dengan kemampuan seseorang untuk menyadari posisi dan gerak yang telah dilakukan (Herywansyah, 2010, p.80).

Gerakan keterampilan groundstrokes termasuk gerakan yang cukup kompleks, sebab gerakan keterampilan groundstrokes merupakan gabungan beberapa gerakan yang harus dilakukan secara terpadu dan selaras. Keberhasilan keterampilan groundstrokes dipengaruhi oleh kemampuan siswa untuk melakukan gerakan secara terpadu dan selaras. Persepsi kinestetik dapat menunjang keberhasilan belajar keterampilan groundstrokes tenis lapangan, karena dengan persepsi kinestetik yang baik, siswa dapat mengontrol gerakan-gerakan yang dilakukan sehingga menjadi lebih akurat. Siswa yang memiliki persepsi kinestetik tinggi memiliki kemampuan untuk lebih cepat menguasai keterampilan groundstrokes, daripada mahasiswa yang memiliki persepsi kinestetik rendah. Oleh karena itu persepsi kinestetik merupakan unsur dasar yang juga harus ditingkatkan, terutama pada siswa yang masih muda usianya. Karena kinestetik sebagai sumber umpan balik dan selalu memberi informasi sensori kepada sistem syaraf pusat mengenai hal-hal yang terkait dengan karakteristik gerakan, seperti arah, posisi dalam ruang, kecepatan, dan aktivasi otot.

Persepsi kinestetik yang dimiliki oleh siswa berbeda-beda, ada yang tinggi dan ada yang rendah, dan ini tentunya akan mempengaruhi terhadap hasil keterampilan groundstrokes. Bagi siswa yang memiliki persepsi 
kinestetik tinggi tentunya akan mudah mengetahui posisi yang benar pada saat gerakan keterampilan groundstrokes, sedangkan bagi siswa yang memiliki persepsi kinestetik rendah akan mengalami kesulitan dalam melakukan posisi atau gerakan, hal ini juga sesuai dengan teori yang diungkapkan di atas. Kebenaran kajian teori di atas juga diperkuat dengan hasil analisis data dalam penelitian yang menunjukkan bahwa perbandingan rata-rata peningkatan keterampilan groundstrokes, pada siswa yang memiliki persepsi kinestetik tinggi dibandingkan dengan siswa yang memiliki persepsi kinestetik rendah; yaitu didapat hasil rata-rata peningkatan sebesar 8.550 bagi siswa yang memiliki persepsi kinestetik tinggi dan didapat hasil rata-rata peningkatan sebesar 9.600 bagi siswa yang memiliki persepsi kinestetik rendah. Ini dikarenakan persepsi kinestetik berkenan dengan kemampuan seseorang untuk menyadari posisi dan gerak yang telah dilakukan.

\section{Pengaruh Interaksi Antara Demonstrasi dan Audio Visual Serta Persepsi Kinestetik Tinggi dan Rendah terhadap Hasil Keterampilan Groundstrokes}

Berdasarkan hasil yang telah dikemukakan pada hasil penelitian di atas bahwa terdapat interaksi yang berarti antara metode demonstrasi dan persepsi kinestetik terhadap hasil keterampilan groundstrokes pada siswa SD Negeri Petinggen Yogyakarta dan SD Negeri Terbansari 1 Yogyakarta. Dari tabel yang disajikan bentuk interaksi nampak bahwa faktorfaktor utama penelitian dalam bentuk dua faktor menunjukkan interaksi yang nyata.

Berdasarkan hasil penelitian yang dicapai, (1) ternyata siswa yang memiliki persepsi kinestetik tinggi dilatih dengan demonstrasi mengalami peningkatan yang lebih besar, urutan kedua (2) siswa yang memiliki persepsi kinestetik tinggi dilatih dengan metode audio visual mengalami peningkatan yang lebih besar, urutan ketiga (3) siswa yang memiliki persepsi kinestetik rendah dengan metode demonstrasi mengalami peningkatan yang lebih besar, dan yang keempat (4) persepsi kinestetik rendah dilatih metode audio visual mengalami keterlambatan. Ini dikarenakan keefektifan yang diterapkan untuk meningkatkan hasil keterampilan groundstrokes tersebut, dipengaruhi oleh tinggi rendahnya persepsi kinestetik yang dimiliki siswa. Menurut Herywansyah (2010, p.80) persepsi kinestetik berkenan dengan kemampuan seseorang untuk menyadari posisi dan gerak yang telah dilakukan. Pemain yang memiliki kualitas persepsi kinestetik yang kurang baik ada kecenderungan sulit untuk mengontrol posisi dan gerak yang telah dilakukan, sebaliknya pemain yang memiliki kualitas persepsi kinestetik yang baik tentu akan mampu mengontrol posisi dan gerak yang telah di lakuakan, sehingga bila gerakan itu benar dan tepat sasaran ada kecenderungan mengulangi posisi atau gerak yang sama dengan kontrol gerakan yang cermat.

Dari hasil penelitian menunjukkan hasil rata-rata peningkatan yang tidak jauh berbeda antara siswa yang memiliki persepsi kinestetik tinggi dengan siswa yang memiliki persepsi kinestetik rendah yaitu sebesar 11.4 bagi siswa yang memiliki persepsi kinestetik tinggi yaitu sebesar 8.60 bagi siswa yang memiliki persepsi kinestetik rendah.

Dari beberapa pembahasan tersebut untuk mengoptimalkan teknik keterampilan groundstrokes siswa, apabila didapat siswa tersebut memiliki persepsi kinestetik rendah maka siswa tersebut lebih cocok dilatih dengan metode demonstrasi dan siswa yang memiliki persepsi kinestetik tinggi lebih cocok dilatih dengan audio visual. Menurut Mangill (2001, p.75) faktor-faktor yang berperan dalam persepsi yaitu: (1) Objek yang dipersepsi, objek menimbulkan stimulus yang mengenai alat indera atau reseptor. Stimulus dapat datang dari luar individu yang mempersepsi, tetapi juga dapat datang dari dalam diri individu yang bersangkutan yang langsung mengenai syaraf penerima yang bekerja sebagai reseptor. (2) Alat indera, syaraf, dan pusat susunan syaraf, alat indera atau reseptor merupakan alat untuk menerima stimulus. Di samping itu juga harus ada syaraf sensoris sebagai alat untuk meneruskan stimulus yang diterima reseptor ke pusat susunan syaraf, yaitu otak sebagai pusat kesadaran. (3) Perhatian, untuk menyadari atau untuk mengadakan persepsi diperlukan adanya perhatian, yaitu merupakan langkah pertama sebagai suatu persiapan dalam rangka mengadakan persepsi. Dari pendapat tersebut bisa diambil kesimpulan, ketika siswa menerima objek yang dipersepsi, dalam hal ini objek persepsinya berupa komunikasi atau gambar yang dilakukan guru, di mana siswa dapat mengetahui dan merasakannya melalui alat indera. Setelah siswa menyadari adanya sebuah komunikasi dengan gurunya, maka siswa akan melakukan sebuah perhatian yang nantinya 
akan menjadikan tinggi rendahnya suatu persepsi siswa.

Kinestetik mengacu pada sensasi dan persepsi anggota tubuh, togok, dan gerakan kepala. Meskipun kemampuan ini kerapkali diabaikan sebagai salah satu indera dasar manusia, kinestetik penting sebagai sumber umpan balik dan selalu memberi informasi sensori kepada sistem syaraf pusat mengenai hal-hal yang terkait dengan karakteristik gerakan, seperti arah, posisi dalam ruang, kecepatan, dan aktivasi otot. Dapat disimpulkan siswa yang memiliki persepsi kinestetik rendah akan memahami secara langsung posisi gerak dari guru atau pelatih selama proses pembelajaran karena demonstrasi guru secara langsung memperaktekkan gerakkan keterampilan groundstrokes sehingga siswa akan memahami posisi untuk melakukan keterampilan groundstrokes. Bagi siswa yang memiliki persepsi kinestetik tinggi lebih cocok dengan metode audio visual. Hal ini dikarenakan sifat dari audio visual untuk lebih giat belajar dan dapat mempermudah mempelajari pesan atau pelajaran, membangkitkan semangat dan motivasi siswa, siswa yang memiliki persepsi kinestetik tinggi akan mudah melakukannya jika dibandingkan bagi siswa yang memiliki persepsi kinestetik rendah. Dari hasil penelitian menunjukkan hasil rata-rata peningkatan yang tidak jauh berbeda antara siswa yang memiliki persepsi kinestetik tinggi dengan siswa yang memiliki persepsi kinestetik rendah yaitu sebesar 11,40 bagi siswa yang memiliki persepsi kinestetik tinggi dan 8,60 bagi siswa yang memiliki persepsi kinestetik rendah.

\section{SIMPULAN}

Berdasarkan hasil analisis data yang telah dilakukan, dapat diperoleh kesimpulan sebagai berikut: (1) ada perbedaan pengaruh yang signifikan antara metode demonstrasi dengan audio visual dalam meningkatkan hasil keterampilan groundstrokes. Pengaruh metode demonstrasi lebih baik dari pada audio visual dalam meningkatkan hasil keterampilan groundstrokes. (2) Ada perbedaan pengaruh yang signifikan antara persepsi kinestetik tinggi dengan persepsi kinestetik rendah terhadap hasil keterampilan groundstrokes. Peningkatan hasil keterampilan groundstrokes pada siswa yang memiliki persepsi kinestetik tinggi lebih baik daripada yang memiliki persepsi kinestetik rendah. (3) terdapat interaksi yang signifikan antara metode pembelajaran dan persepsi kinestetik terhadap hasil keterampilan groundstrokes tenis lapangan, (a) siswa yang memiliki persepsi kinestetik tinggi lebih cocok jika diberikan metode audio visual, (b) siswa yang memiliki persepsi kinestetik rendah lebih cocok jika diberikan metode demonstrasi.

\section{DAFTAR PUSTAKA}

Amien, S., \& Lamere, F. (2010). Media audio dan video untuk pembelajaran. http://benramt.wordpress.com/2010/01/1 8/media-audio-dan-videountukpembelajaran/diambil pada tanggal 24 Oktober 2013.

Suyitno, A. (2005). Pemilihan model-model pembelajaran matematika dan penerapannya di sekolah dasar. Semarang: Jurusan Matematika FMIPA UNNES Semarang.

Saifuddin, A. (2010). Metode penelitian. Yogyakarta: Pustaka Pelajar Offset.

Arsyad, A. (2009). Media pembelajaran. Jakarta: Rajawali Pers.

Balnavas, M. (2001). Introduction to quantitative research methods. UK: Sage Publications Ltd.

Bornemann, R., et al. (2000). Tennis course volume 1: Techniques an tactics, English language edition. Hauppauge, NY: Barron's Educational Series, Inc.

Bornemann, R., et al. (2000). Tenis course volume 2.lesson and training, English language editon. Hongkong: Barron' s Educational series, Inc.

Brown, J. (2001). Tenis tingkat pemula (terjemahan). Jakarta: Raja Grafindo Persada.

Rahyubi, H. (2012). Teori-teori belajar dan aplikasi pembelajaran motorik: Deskripsi dan tinjauan kritis. Bandung: Nusa Media.

Hariono, A. (2008). Pengaruh metode mengajar dan koordinasi terhadap kemampuan groundstrokes petenis pemula. Tesis. Solo: Program Pascasarjana UNS.

Herywansyah. (2010). Perbedaan pengaruh pendekatan pembelajaran dan persepsi kinestetik terhadap hasil tembakanlay up bolabasket. Tesis. Solo: Pascasarjana UNS. 
Mundaru. (2006). Olahraga alternatif badminton dan tenis. Diambil pada tanggal 13 Desember 2012 dari http://www.suara merdeka. com/harian/0603/29/ora15. htm.

Sumantri, M., \& Permana, J. (2001). Strategi belajar mengajar. Bandung: CV. Maulana.

Martono, N. (2012). Metode penelitian kuantitatif; analisis isi dan analisis data sekunder. Edisi Revisi. Jakarta: Rajawali Pers.

Sudiro. (2008). Pembelajaran teknik groundstrokes melalui metode mini tenis bagi petenis pemula. Tesis, tidak diterbitkan. Yogyakarta: Universitas Negeri Yogyakarta.

Sudjana. (2002). Desain dan analisis eksperimen. Bandung: Tarsito.

Sukadiyanto. (2004). Keterampilan groundstrokes petenis pemula, studi eksperimen pada siswa SD di Kabupaten Sleman, Daerah Istimewa Yogyakarta. Disertasi, tidak diterbitkan, Jakarta: Universitas Negeri Jakarta.

Sukadiyanto. (2003). Teori dan metodologi melatih fisik petenis. Yogyakarta: Fakultas Ilmu Keolahragaan UNY. 